\title{
PENERAPAN PENDEKATAN KONTEKSTUAL UNTUK MENINGKATKAN KETERAMPILAN MENULIS LAPORAN SISWA KELAS VIII SMP
}

\author{
Ary Kristiyani \\ Fakultas Bahasa dan Seni Universitas Negeri Yogyakarta \\ e-mail: ary_kris@yahoo.com
}

\begin{abstract}
This study aimed to describe the improvement of the quality of the report writing learning process and the improvement of students' report writing skills through the contextual approach. This study was an action research study employing John Elliott's model consisting of two cycles. The subjects were Year VIII E students of SMP Negeri 1 Juwana. The data were collected through tests, observations, field notes, and interviews and were analyzed by means of the qualitative and quantitative descriptive techniques. The results showed that: (1) the learning of report writing was better than that conducted before; (2) students' writing skills at the end of Cycle II (9.03) were better (mean $=9.03$ ) than those before the action (mean =7.71). Therefore, it was concluded that the application of CTL was capable of improving the quality of the report writing learning and the report writing skills of Year VIII E students of SMP Negeri 1 Juwana.
\end{abstract}

Keywords: report writing skills, contextual teaching learning

\section{PENDAHULUAN}

Pembelajaran bahasa Indonesia di SMP Negeri 1 Juwana, terutama pembelajaran menulis laporan masih jauh dari yang diharapkan. Guru hanya memberikan sebuah contoh laporan, kemudian siswa mencontoh laporan yang diberikan oleh guru. Siswa tidak diberikan kesempatan untuk menemukan sendiri dan melakukan observasi secara langsung terhadap suatu objek sebagai sumber pengamatan. Selain itu, guru belum memanfaatkan berbagai fasilitas dalam pembelajaran, seperti $O H P$, perpustakaan, komputer, LCD, dan lingkungan sekolah. Hal ini berdampak pada rendahnya motivasi, minat, dan kemampuan siswa terhadap pembelajaran bahasa Indonesia, khususnya pembelajaran menulis laporan. Masih rendahnya kemampuan menulis disebabkan siswa merasa sulit untuk menulis. Banyak siswa yang kurang berminat menulis, terutama menulis laporan. Hal seperti ini dapat dilihat dari hasil tulisan siswa pada majalah dinding yang hanya berupa puisi, gambar, dan tips.

Dengan melihat kondisi tersebut diperoleh indikasi bahwa pola pembelajaran yang diajarkan yaitu dengan menggunakan pola baru (KBK) masih sangat dipengaruhi cara lama atau tradisional, penggunaan teknik dan strategi tidak diimplementasikan dalam pembelajaran, guru sangat dominan dalam pembelajaran. Bila hal tersebut didiamkan dan tidak dicarikan solusinya, pembelajaran bahasa Indonesia terutama keterampilan menulis laporan berlangsung tidak efektif dan tidak efisien sehingga hal itu akan mempengaruhi hasil prestasi dan kompetensi yang diharapkan pada diri siswa tidak dapat terwujud seperti yang diharapkan Kurikulum Berbasis Kompetensi. 
Berdasarkan pemikiran dan kenyataan yang ada, perlu dilakukan pemecahan mengenai permasalahan tersebut dengan penerapan pendekatan kontekstual dalam pembelajaran bahasa Indonesia, terutama pembelajaran menulis laporan. Sejalan dengan itu, untuk meningkatkan kualitas pembelajaran keterampilan menulis laporan dan peningkatan kompetensi siswa dipandang perlu diberikan masukan perbaikan dalam pembelajaran dan pengembangan menulis, terutama pada keterampilan menulis laporan dengan penerapan pendekatan kontekstual.

Penerapan pendekatan kontekstual (Contextual Teaching Learning) memungkinkan siswa untuk menguatkan dan menerapkan keterampilan yang mereka peroleh dari berbagai mata pelajaran, baik di sekolah maupun di luar sekolah. Siswa dilatih untuk dapat memecahkan masalah yang mereka hadapi dalam suatu situasi. Bila CTL diterapkan dengan benar, diharapkan siswa akan terlatih untuk dapat menghubungkan apa yang diperoleh di kelas dengan kehidupan nyata yang dialami yang ada di lingkungannya. Tugas guru sebagai fasilitator memberikan pengarahan dan bimbingan kepada siswa sehingga pembelajaran keterampilan menulis laporan secara kontekstual dapat diterapkan dengan benar agar siswa dapat belajar lebih efektif. Dalam hal ini tugas guru adalah membantu mencapai tujuan pembelajaran.

Konsep dasar pendekatan kontekstual diperkenalkan pertama kali tahun 1916 oleh John Dewey, yang menyatakan, "Kurikulum dan metodologi pembelajaran seharusnya erat berhubungan dengan minat dan pengalaman siswa." "Proses belajar akan lebih efektif bila pengetahuan baru yang diberikan kepada siswa berdasarkan pengalaman atau pengetahuan yang sudah dimiliki siswa sebelumnya" (Kasihani, 2003).
Definisi pembelajaran kontekstual dikemukakan oleh Gafur (2003) yang menyatakan, "Pembelajaran kontekstual memandang proses belajar benar-benar berlangsung hanya jika siswa mampu memproses atau mengonstruksi sendiri informasi atau pengetahuan sedemikian rupa tepatnya sehingga pengetahuan menjadi bermakna sesuai dengan kerangka pikir mereka."

Berdasarkan pendapat di atas dapat disimpulkan bahwa pendekatan kontekstual dalam pembelajaran bahasa adalah kemampuan siswa mengonstruk sendiri pengetahuan dan memberikan makna pemahamannya dalam pengalaman nyata. Dengan kata lain, pemahaman berkembang dalam pengalaman belajar bermakna.

Menurut US Departement of Education, Contextual Teaching and Learning adalah: "Suatu konsep mengajar dan belajar yang membantu guru menghubungkan kegiatan dan bahan ajar mata pelajarannya dengan situasi nyata yang dapat memotivasi siswa untuk menghubungkan pengetahuan dan menerapkannya dalam kehidupan sehari-hari sebagai anggota keluarga, bahkan sebagai anggota masyarakat tempat dia hidup" (Berns, 2001). Sebagaimana dikemukakan oleh Clifford dan Wilson (Susan, 2000), pembelajaran kontekstual memiliki karakteristik antara lain: (1) menekankan pada problem solving; (2) proses belajar mengajar diusahakan terjadi pada multiple context; (3) membantu siswa belajar bagaimana memonitor belajarnya sehingga menjadi individu mandiri (self-regulated learners); (4) pengajaran bermuara pada berbagai macam konteks kehidupan siswa (life skill education); (5) mendorong siswa untuk belajar dari sesamanya (cooperative learning); dan (6) menerapkan authentic assessment. Pada pelaksanaan pembelajaran bahasa Indonesia, terdapat tujuh komponen CTL yang diterapkan dalam proses belajar 
mengajar, yaitu: (1) konstruktivisme (constructivism), menemukan (inquiry), bertanya (questioning), masyarakat belajar (learning community), pemodelan (modeling), refleksi (reflection), penilaian yang sebenarnya (authentic assessment).

Keraf (1980) mengatakan bahwa laporan adalah suatu cara komunikasi untuk menyampaikan informasi kepada seseorang atau suatu badan karena tanggung jawab yang dibebankan kepadanya. Adapun Hans E. Kawulusan (1983) yang mengambil pendapat de Boer menyatakan, "Laporan tertulis itu dibuat oleh penulis untuk menyampaikan fakta-fakta, gagasan-gagasan, pendapatpendapat, atau perasaan-perasaan kepada pembaca, dan bahwa penyampaian itu harus dilakukan dengan cara yang seobjektif mungkin." Dalam hubungannya dengan laporan ini Barnett (1974: 21) menyatakan, "Penulisan laporan termasuk ke dalam informative writing, yaitu tulisan yang terutama bertujuan untuk memindahkan pengetahuan yang dimiliki oleh penulis kepada pembaca atau kepada orang lain yang menerima laporan itu." "Ditinjau dari bentuknya, laporan termasuk jenis karangan paparan dan jenis karangan paparan adalah: (a) penulisan surat, (b) penulisan laporan, (c) timbangan buku, resensi buku, dan (d) rencana penelitian" (Chenfeld, 1978).

Harris dan Halim (Nurgiyantoro, 2001: 306) mengatakan bahwa penilaian menulis laporan berdasarkan model pendekatan analitis, misalnya analisis unsur-unsur karangan. Unsur-unsur yang dimaksud adalah content (isi, gagasan yang dikemukakan), form (organisasi isi), grammar (tata bahasa dan pola kalimat), style (gaya: pilihan struktur dan kosakata), dan mechanics (ejaan).

Lebih lanjut, Harris dan Halim (Nurgiyantoro, 2001) mengemukakan bahwa untuk keperluan praktis, guru perlu menentukan bobot atau besarnya "porsi" untuk tiap-tiap unsur tersebut." Bobot yang diberikan mungkin sama, misalnya seperti model skala (1 sampai dengan 10). Akan tetapi, mungkin guru menganggap tidak adil jika setiap unsur diberikan bobot yang sama. Idealnya pembobotan itu mencerminkan tingkat pentingnya tiap-tiap unsur dalam karangan. Dengan demikian, unsur yang lebih penting diberikan bobot yang lebih tinggi.

\section{METODE}

Penelitian ini termasuk jenis Penelitian Tindakan Kelas (PTK) atau Classroom Action Research. Penelitian ini bersifat reflektif dengan melakukan tindakan-tindakan tertentu agar dapat memperbaiki dan meningkatkan praktik pembelajaran yang terjadi di dalam kelas.

Subjek penelitian adalah siswa Kelas VIII E SMP Negeri 1 Juwana semester 1 tahun akademik 2007/2008 yang berjumlah 40 orang. Penentuan subjek penelitian berdasarkan observasi awal yang menemukan permasalahan dalam pembelajaran keterampilan menulis, khususnya menulis laporan. Dalam penelitian dilakukan kolaborasi dengan guru bahasa Indonesia yang mengampu kelas tersebut. Di samping itu, guru bahasa Indonesia Kelas IX juga bersedia sebagai kolaborator penelitian. Jadi, dalam penelitian ini terdapat dua kolaborator. Pengumpulan data pada penelitian tindakan kelas ini dilakukan dengan menggunakan catatan lapangan, lembar observasi, wawancara, dan tes yang dilakukan dalam setiap siklus semua itu digunakan mengetahui sejauh mana tingkat keterampilan menulis laporan siswa Kelas VIII E SMP Negeri 1 Juwana.

Catatan lapangan berisi deskripsi tentang pengamatan terhadap tindakan sewaktu dilaksanakan pembelajaran bahasa Indonesia dengan mengguna- 
kan pendekatan kontekstual. Catatan lapangan memuat interaksi siswa dan guru serta aktivitas yang dilakukan dengan langkah-langkah perencanaan pembelajaran yang telah disusun.

Observasi dilakukan untuk mengamati suasana kelas saat berlangsungnya pembelajaran, materi, aktivitas siswa, metode yang digunakan sudah sesuai dengan pendekatan kontekstual selama pembelajaran berlangsung. Wawancara dimaksudkan untuk memperoleh data yang diungkapkan melalui kata-kata secara lisan tentang sikap, pendapat mengenai proses praktik pembelajaran guru yang berlangsung dalam kelas. Tes digunakan untuk mengukur kemampuan siswa dalam pembelajaran. Tes yang diberikan adalah tes tertulis, yang diberikan pada awal pembelajaran (pretest) dan pada akhir pembelajaran (post-test).

Dalam penelitian ini digunakan teknik analisis deskriptif kualitatif dan kuantitatif untuk mendeskripsikan keterampilan menulis laporan sebelum dan sesudah implementasi tindakan. Data yang diperoleh dalam penelitian ini diolah dengan menggunakan langkah-langkah kegiatan: (a) reduksi data; (b) penyajian data; dan (c) penyimpulan data. Teknik validitas data yang digunakan adalah triangulasi, validitas demokratik, dan validitas dialogis.

Triangulasi yang digunakan adalah jenis triangulasi data situasional dan metode pengumpulan data. Triangulasi data situasional yaitu triangulasi dengan mengamati objek yang sama dalam berbagai situasi. Triangulasi metode adalah teknik keabsahan data yang dilakukan dengan menggunakan beberapa alat instrumen agar data yang terkumpul lebih akurat. Teknik ini ditempuh dengan menggunakan pedoman pengamatan dan pedoman wawancara.

Democratic validity digunakan untuk memberikan kesempatan pada peneliti agar benar-benar kolaboratif dan menerima masukan dari berbagai pendapat. Kuncinya, semua yang terlibat dalam penelitian (kepala sekolah, guru, dan siswa) dapat menawarkan masukan, ide, pendapat, dan komentar tentang implikasi penelitian. Dialogic validity dilakukan antara peneliti dan kolaborator. Mereka berdialog menanggapi penelitian yang dilakukan.

\section{HASIL DAN PEMBAHASAN Keberhasilan Proses}

Pada pembelajaran bahasa Indonesia untuk meningkatkan kualitas pembelajaran menulis laporan dan meningkatkan keterampilan menulis laporan siswa Kelas VIII E melalui pendekatan kontekstual diamati beberapa aspek. Aspek-aspek yang yang dimaksud, yaitu (1) mengonstruksi atau Membangun Pengetahuan Sendiri (Constructivism), (2) menemukan pengetahuan sendiri (inquiry), (3) merespons materi yang diberikan dalam rangka menggali informasi untuk meningkatkan keterampilan menulis laporan (questioning), (4) mendiskusikan tema dalam upaya meningkatkan keterampilan menulis laporan (learning community), (5) memodelkan atau melakukan observasi (modeling), (6) merefleksi materi pembelajaran menulis laporan (reflection, dan (7) keautentikan penilaian (authentic asssessment)

Kemampuan siswa untuk mengonstruk sendiri pengetahuan dengan pendekatan kontekstual dalam pembelajaran bahasa Indonesia, dengan langkah-langkah seperti berikut. Pertama, pengetahuan dan keterampilan siswa diperoleh dari proses menemukan sendiri: siswa mencermati dengan seksama materi menulis laporan. Kedua, pengetahuan dan keterampilan siswa diperoleh dengan konteks yang terbatas, sesuai dengan kompotensi yang dicapai, yaitu keterampilan menulis laporan ha- 
sil pengamatan. Ketiga, dalam pembelajaran terdapat kegiatan menemukan: kegiatan menemukan dan menentukan tema yang menarik dan menemukan data-data hasil pengamatan.

Menemukan merupakan bagian inti dari kegiatan pembelajaran CTL. Pengetahuan dan keterampilan yang diperoleh siswa bukan hasil mengingat seperangkat fakta-fakta, melainkan hasil dari menemukan sendiri. Kemampuan siswa untuk menemukan pengetahuan sendiri dalam pembelajaran bahasa Indonesia dengan pendekatan kontekstual dilakukan dengan langkahlangkah: (1) siswa mengamati objek: kegiatan mengamati objek yang menarik di lingkungan sekolah, yaitu mencari dan mengumpulkan data hasil pengamatan, (2) siswa berani mengajukan pendapat tentang materi pembelajaran menulis laporan, (3) kegiatan pembelajaran dipusatkan pada siswa, dan (4) pemberian tugas untuk menyusun kerangka laporan dan menulis laporan secara individual.

Dalam pembelajaran bahasa Indonesia di kelas, guru mengajukan pertanyaan untuk menggali informasi, merangsang siswa berpikir, mengevaluasi pembelajaran, memperjelas gagasan, dan meyakinkan apa yang diketahui siswa. Aspek positif kegiatan bertanya yang terjadi di dalam kelas adalah: (1) siswa berani bertanya dan mengemukakan pendapat mengenai kerangka laporan dan materi yang diberikan, (2) beberapa siswa antusias dalam menjawab pertanyaan guru, (3) untuk menyelesaikan masalah, siswa bertanya kepada siswa yang lain selain guru, dan (4) pada umumnya siswa bertanya tentang bagaimana cara mempelajari sesuatu daripada bertanya yang hanya meminta informasi.

Penerapan masyarakat belajar atau belajar berkelompok dalam pembelajaran bahasa Indonesia telah memberi- kan kontribusi pada proses pembelajaran. Dalam masyarakat belajar, kegiatan masyarakat belajar ditandai dengan kegiatan seperti: (1) siswa terlibat aktif belajar bersama, berbagi informasi dan pengalaman, saling merespons, dan saling berkomunikasi sesama teman untuk mengemukakan pendapatnya; (2) peembagian kelompok secara heterogen memberikan pengaruh positif, terutama sharing keilmuan atau pengetahuan di antara siswa; dan (3) siswa belajar berkelompok untuk mendiskusikan materi yang diberikan, seperti menemukan tema yang menarik, melakukan observasi, dan menyusun kerangka laporan untuk meningkatkan keterampilan menulis.

Kegiatan pemodelan sangat mendukung dalam kegiatan pembelajaran. Realisasi kegiatan ini berupa hal-hal seperti: (1) pemodelan dilakukan sesama siswa (siswa yang mempunyai kemampuan kebahasaan), (2) siswa mempresentasikan hasil diskusi di depan kelas, (3) siswa giat, serius, dan antusias dalam memperloleh data seoptimal mungkin melalui kegiatan pengamatan, (4) siswa lain mencontoh teman atau kelompok yang melakukan pengamatan secara mendalam, (5) guru memberikan contoh menulis laporan hasil pengamatan dengan menggunakan bahasa Indonesia baku, dan (6) siswa meniru penggunaan bahasa Indonesia baku dalam menulis laporan hasil pengamatan.

Merefleksi kegiatan pembelajaran dengan jalan memberikan respons terhadap kejadian, aktivitas, atau pengetahuan yang diterima merupakan bagian penting dalam pembelajaran kontekstual. Aspek merefleksi materi dalam pembelajaran menulis laporan adalah: (1) siswa memberikan respons terhadap pembelajaran yang dihubungkan dengan pengalaman nyata siswa itu sendiri, terutama pengetahuan yang mengendap dalam diri siswa sebagai 
struktur pengetahuan baru; (2) siswa mampu merefleksi dan memberikan respons terhadap pembelajaran yang sedang berlangsung dan pada akhir pembelajaran; dan (3) sebagian refleksi muncul dari siswa.

Penilaian pembelajaran bahasa Indonesia tidak hanya terpaku pada penilaian dalam bentuk tes saja, namun penilaian nyata dilakukan juga pada saat proses pembelajaran bahasa Indonesia berlangsung. Aspek penilaian ini mencakup: (1) pada proses pembelajaran siswa mampu menjawab pertanyaan yang diberikan guru selama pembelajaran, (2) selama proses pembelajaran siswa aktif dalam proses pembelajaran, dan (3) siswa mampu melakukan penilaian terhadap laporan hasil pengamatan temannya.

\section{Sikap Siswa terhadap Pembelajaran Bahasa Indonesia dengan Penerapan Pendekatan Kontekstual}

Sikap merupakan suatu kecenderungan persepsi psikologis sesorang terhadap suatu objek. Seseorang mempunyai kecenderungan untuk menyatakan rasa senang, melakukan penerimaan, ataupun memperoleh kepuasan, dan perhatian pada objek tertentu. Sikap seseorang terhadap sesuatu dicerminkan melalui tingkah laku terhadap objek tersebut, baik dengan perasaan tidak memihak atau menyenangi, maupun dengan perasaan tidak memihak atau tidak menyenangi pada sebuah objek.

Sikap positif siswa terhadap pembelajaran bahasa Indonesia sangat berpengaruh terhadap hasil pembelajaran bahasa Indonesia, baik bagi guru maupun siswa itu sendiri. Pembelajaran bahasa Indonesia dengan penerapan pendekatan kontekstual telah memberikan konstribusi yang baik, terutama dalam hal: (1) motivasi dan minat siswa terhadap pembelajaran bahasa indonesia; dan (2) pengetahuan menulis laporan siswa

Motivasi dan minat merupakan salah satu faktor psikologis yang sangat berpengaruh terhadap prestasi belajar. Motivasi dan minat merupakan faktor yang sangat penting dalam belajar. Belajar akan optimal kalau ada motivasi. Makin tepat motivasi yang diberikan, makin berhasil pelajaran itu. Berbagai upaya telah dilakukan guru untuk menumbuhkan sikap positif dalam pembelajaran bahasa Indonesia, terutama dalam rangka untuk meningkatkan keterampilan menulis laporan siswa. Penerapan CTL dalam pembelajaran menulis laporan telah memberikan kontribusi dalam pembelajaran bahasa Indonesia dengan indikator sebagai berikut. Pertama, adanya sikap positif siswa terhadap pembelajaran di kelas, terutama interaksi positif dengan guru dan antara siswa dengan materi yang disajikan dalam pembelajaran bahasa Indonesia, khususnya menulis laporan. Kedua, siswa merespons kegiatan pembelajaran. Penerapan CTL mengajak siswa menikmati pembelajaran secara langsung, khususnya dalam memahami materi pembelajaran untuk meningkatkan keterampilan menulis laporan mereka. Ketiga, respons siswa sangat baik terhadap kegiatan pramenulis laporan, terutama apabila diminta untuk melakukan observasi, menyusun kerangka laporan, dan mengembangkan kerangka laporan menjadi beberapa paragraf dengan menggunakan bahasa Indonesia baku. Keempat, kesan siswa terhadap pembelajaran menulis laporan: menambah pengetahuan dan meningkatkan keterampilan menulis laporan siswa.

Berdasarkan uraian di atas dapat disimpulkan bahwa motivasi dan minat siswa dalam pembelajaran bahasa Indonesia, terutama menulis laporan cukup tinggi. Siswa termotivasi dan senang untuk melakukan observasi secara langsung di lingkungan sekolah. Adanya mi- 
nat yang besar terhadap pembelajaran menulis laporan ditunjukkan dengan sikap positif dan berani mengemukakan pikiran, ide, gagasan, argumen, dan sanggahan dalam pembelajaran menulis laporan.

Selanjutnya, pengetahuan menulis laporan siswa selama ini belum memadai. Pengetahuan menulis laporan, terutama pramenulis laporan yang dimiliki siswa hanya sebatas teori atau tugas yang harus dikerjakan. Selama ini, pendekatan yang digunakan guru belum memberdayakan kemampuan siswa sehingga mereka tidak termotivasi untuk aktif dan kreatif dalam melakukan kegiatan belajar menulis laporan.

Pemilihan pendekatan kontekstual merupakan upaya yang ditempuh guru untuk memberikan motivasi pada siswa agar siswa lebih aktif, kreatif, dan dapat memberdayakan kemampuan dirinya dalam melakukan kegiatan menulis laporan. Penerapan CTL dalam pembelajaran bahasa Indonesia telah memberikan manfaat, sebagai berikut. Pertama, menambah variasi metode pembelajaran yang diterapkan guru. Pembelajaran bahasa Indonesia, khususnya menulis laporan menggunakan pendekatan kontekstual menarik dan menambah pengetahuan siswa. Kedua, dalam pembelajaran menulis laporan dengan menggunakan pendekatan kontekstual, siswa diajak untuk menemukan dan menentukan tema yang menarik di lingkungan sekolah, melakukan pengamatan, menyusun kerangka laporan, dan dapat meningkatkan keterampilan menulis laporan yang mereka miliki. Ketiga, penerapan CTL dalam pembelajaran menulis laporan menyebabkan siswa terbiasa berpraktik secara langsung sehingga akan meningkatkan keterampilan menulis laporan siswa menjadi lebih baik.
Berdasarkan uraian di atas dapat disimpulkan bahwa pembelajaran menulis laporan yang dilakukan oleh guru selama ini sebatas teori atau tugas yang harus dilakukan sehingga siswa tidak memperoleh pengalaman yang nyata dalam pembelajaran. Dengan pendekatan kontekstual kemampuan siswa makin meningkat dalam menulis laporan, siswa menjadi kreatif, aktif, dan terbiasa praktik secara langsung. Dengan demikian, keterampilan menulis laporan siswa meningkat.

\section{Keberhasilan Produk}

Alat ukur yang dipergunakan untuk mengetahui peningkatan keterampilan menulis laporan bahasa Indonesia siswa, baik sebelum dan sesudah diberikan tindakan adalah tes menulis laporan. Pada pretest, siswa diminta menulis laporan berdasarkan pengalaman mereka atau dengan tema bebas (menarik bagi mereka), sedangkan post-test siswa diminta membuat laporan pengamatan dengan tema di sekitar lingkungan sekolah.

Tes diberikan pada setiap siklus, yaitu siklus pertama dan kedua. Pada pretest siswa belum mengetahui sistematika menulis laporan dan tidak menggunakan bahasa baku dalam menulis laporan. Menulis laporan termasuk tulisan yang bersifat resmi, objektif, realistis, dapat dipertanggungjawabkan, dan bersifat ilmiah. Setelah diberikan tiga kali tindakan dalam setiap siklusnya, hasil tes menulis laporan mengalami peningkatan. Hal ini menunjukkan adanya peningkatan pemahaman siswa terhadap materi menulis laporan, terutama pada sistematika dan penggunaan bahasa baku dalam menulis laporan. Berikut ini disajikan hasil tes menulis laporan siswa Kelas VIII E. Hasil tes menulis laporan dapat dilihat pada Tabel 1 dan Tabel 2 berikut. 
Tabel 1 Deskripsi Nilai Tes (Per Siklus) Peningkatan Keterampilan Menulis Laporan Siswa Kelas VIII E SMP Negeri 1 Juwana

\begin{tabular}{cccc}
\hline Nilai & $\begin{array}{c}\text { Prasurvei/ } \\
\text { Pretes }\end{array}$ & Siklus I & Siklus II \\
\hline 50 & 9 & - & - \\
55 & 13 & - & - \\
60 & 18 & 13 & - \\
65 & - & 16 & - \\
70 & - & 7 & - \\
75 & - & 2 & 19 \\
80 & - & 2 & 16 \\
85 & - & - & 3 \\
90 & - & - & 2 \\
Jumlah & 2245 & 2620 & 3140 \\
Rata-rata \% & & 7.71 & 9.03 \\
Rata-rata & 56.12 & 65.50 & 78.50 \\
\hline
\end{tabular}

Tabel 2 Analisis Nilai Peningkatan Keterampilan Menulis Laporan Siswa Kelas VIII E SMP Negeri 1 Juwana Per Siklus

\begin{tabular}{lccccc}
\hline \multicolumn{1}{c}{ Skor } & N & Nilai Terendah & Nilai Tertinggi & Mean & Std. Deviasi \\
\hline Presurvei & 40 & 50 & 60 & 56.12 & 4.685 \\
Siklus I & 40 & 60 & 80 & 65.50 & 6.660 \\
Siklus II & 40 & 75 & 90 & 78.50 & 7.256 \\
\hline
\end{tabular}

Pada Siklus I, nilai yang diperoleh siswa menunjukkan suatu peningkatan yang bertahap. Nilai pretest atau prasurvei sebesar 56.12. Siklus I sebesar 65.50, dengan persentase kenaikan sebesar $7.71 \%$. Pada Siklus I, nilai terendah 60, tertinggi 80, dan mean 65.50 dengan standar deviasi 6.660. Hasil ini menggambarkan bahwa proses pembelajaran masih perlu penajaman dalam materi menulis laporan dan penggunaan bahasa Indonesia baku dalam menulis laporan.

Pada akhir Siklus II, skor rerata yang diperoleh siswa meningkat menjadi 78.50. Nilai terendah 75 , tertinggi 90, standar deviasi sebesar 7.256, dan persentase kenaikan sebesar $9.03 \%$. Selisih antara pretest Siklus I dan post-test Siklus II sebesar 22.38 atau $16.62 \%$ mem- berikan informasi adanya keberhasilan pembelajaran dengan menggunakan pendekatan kontekstual dan adanya peningkatan keterampilan menulis laporan pada siswa Kelas VIII E SMP Negeri 1 Juwana.

\section{SIMPULAN}

Penerapan pendekatan kontekstual dapat meningkatkan kualitas pembelajaran bahasa Indonesia, khususnya menulis laporan hasil pengamatan pada siswa Kelas VIII E SMP Negeri 1 Juwana. Peningkatan kualitas proses pembelajaran menulis laporan dapat ditunjukkan oleh kondisi berikut ini: (a) siswa terlatih untuk bernalar dan berpikir secara kritis terhadap materi pramenulis laporan dan menulis laporan; (b) siswa penuh dengan aktivitas dan antusias 
untuk menemukan tema; (c) siswa berani mengajukan pertanyaan dan informasi atau hal-hal yang tidak sesuai dengan pendapat mereka; (d) siswa terlatih untuk belajar 'sharing ideas' saling berbagi pengetahuan dan berkomunikasi; (e) siswa dapat memberikan contoh melakukan pengamatan terhadap suatu objek di lingkungan sekolah secara giat, serius, dan antusias untuk memperoleh data seoptimal mungkin; (f) Refleksi yang dilakukan, baik selama pembelajaran berlangsung maupun dalam setiap akhir pembelajaran berlangsung; (g) penilaian menekankan pada proses dan hasil pembelajaran, seperti: presentasi atau penampilan siswa selama: berdiskusi, melakukan observasi, mendemonstrasikan, dan hasil menulis laporan; selain itu, setiap siswa melakukan penilaian terhadap laporan yang yang ditulis oleh temannya.

Penerapan pendekatan CTL dapat meningkatkan keterampilan menulis laporan siswa Kelas VIII E SMP Negeri 1 Juwana. Keterampilan menulis laporan siswa sebelum dilakukan tindakan dan setelah dilakukan tindakan mengalami peningkatan yang berarti. Alat ukur yang digunakan untuk mengetahui peningkatan keterampilan menulis laporan siswa adalah tes. Tes diberikan sebelum tindakan (pretest) dan setelah tindakan (post-test) dalam setiap siklusnya. Pada Siklus I skor rerata pretest adalah 56.12 dan post-test 65.50 dengan persentase kenaikan menjadi $7.71 \%$. Hasil ini menggambarkan proses pembelajaran masih perlu penajaman dalam pemberian materi menulis laporan. Pada akhir Siklus II skor rerata yang diperoleh siswa meningkat menjadi 78.50; persentase sebesar $9.03 \%$. Selisih antara pretest Siklus I dan post-test Siklus II sebesar 22.38 atau $16.62 \%$ memberikan informasi adanya keberhasilan pembelajaran dengan menggunakan pendekatan kontekstual dan adanya peningkatan keterampilan menulis laporan pada siswa Kelas VIII E SMP Negeri 1 Juwana.

Berdasarkan kesimpulan dan pembahasan yang telah diuraikan sebelumnya, dapat dikemukakan implikasi penelitian ini sebagai berikut. Pendekatan kontekstual (CTL) dapat digunakan dalam pembelajaran bahasa Indonesia, khususnya menulis laporan. Pendekatan ini dapat meningkatkan kualitas proses pembelajaranketerampilan menulis laporan. Siswa mampu meningkatkan pemahaman dan keterampilan menulis laporan. Selain itu, siswa mendapat pengalaman yang berharga dari proses pembelajaran dengan menggunakan pendekatan kontekstual (CTL). Guru dapat mempraktikkan pendekatan ini agar siswa lebih memperhatikan proses pembelajaran dan lebih mampu menyerap esensi pembelajaran bahasa Indonesia, khususnya menulis laporan terhadap kehidupan pribadinya di masyarakat dan lingkungan sosial mereka.

\section{UCAPAN TERIMA KASIH}

Ucapan terima kasih disampaikan kepada Bapak/Ibu Guru Bahasa Indonesia dan para siswa kelas VIII di SMP Negeri 1 Juwana yang telah membantu pelaksanaan penelitian. Selanjutnya ucapan terima kasih disampaikan kepada dua reviewer anonim yang telah membaca, mengoreksi dan memberi masukan terhadap artikel ini.

\section{DAFTAR PUSTAKA}

Gafur, Abdul. 2003. “Penerapan Konsep dan Prinsip Pembelajaran Kontekstual (Contextual Teaching and Learning) dan Desain dalam Pengembangan Pembelajaran dan Bahan Ajar". Jurnal Cakrawala Pendidikan. November 2003: Tahun XXII. No. 3. Yogyakarta: LP3M UNY. 
Bern, R. G. \& Erickson, P. M. 2001. Contextual Teaching and Learning; The Highglight Zone; Research @ Work No. 5. http://ncete.org/ publication/ infosythensis/index. as. Diunduh tanggal 14 Juni 2007

Nurgiyantoro, Burhan. 2001. Penilaian dalam Pengajaran Bahasa dan Sastra. Yogyakarta: BPFE-Yogyakarta.

Chenfeld, Mimi Brodsky. 1978. Teaching Language Creatively. New York: Harcourt Brace \& World.

Kasihani, E.K. 2003. Contextual Teaching and Learning (CTL) dalam Pengajaran dan Pembelajaran Bahasa. Makalah disajikan pada TOT 'Contextual Teaching and
Learning' Bidang Studi Bahasa Inggris di Universitas Negeri Malang.

Keraf, Gorys. 1980. Komposisi sebuah Pengantar Kemahiran Bahasa. EndeFlores: Nusa Indah.

Kawulasan, Hans E.. 1993. "Bahasa Indonesia dalam Penulisan Laporan". Dalam Amran Halim, Konggres Bahasa Indonesia III. Jakarta: Pusat Pembinaan dan Pengembangan Bahasa.

Susan, Imel. 2000. "Contextual Learning in Adult Education". Http:// www.cete.org/acve/ textony/ 120. Diambil tanggal 14 Juni 2005 